\title{
Position of Emergency Medical Technician in Rescue Team in Traffic Accidents
}

\author{
Goran Perge*, Milan Bagic and Damir Kustric \\ Department of Medical Emergency, Serbia
}

Submission: January 21, 2018; Published: March 22, 2018

*Corresponding author: Goran Perge, Emergency Medical Department, Stari sor 65, Sremska Mitrovica, Serbia, Email: gperge@live.com

\begin{abstract}
Emergency medical technician plays important role in saving traffic accidents victims. Emergency medical teams in Serbia consist of three members: a doctor, a EMT and a driver. In accidents with one victim, each member has specific position. For treating patients system "Stay and Play" is used in Serbia. It means that all procedures are done on the scene. EMT is doctor's assistant in some procedures such as endotracheal intubation, aspiration, monitoring, immobilizing etc. Some procedures have to be done by EMT alone or with firefighter or policeman as chief of the team. For instance: cervical spine stabilization with collar, extremity immobilization, IV cannulation, fixation of the patient on board etc. Extraction from the wreckage is specific. EMT has to stabilize head and cervical spine and coordinate between doctor and firefighters at the same time.
\end{abstract}

Keywords: Emergency medical technician; Traffic accident; Team position

Abbreviations: EMT: Emergency Medical Technician; Sp02: Peripheral Capillary Oxygen Saturation

\section{Introduction}

Emergency medical teams in Serbia consist of three members: a doctor, a EMT and a driver. All of them have specific position in taking care of wounded in traffic accidents.

\section{Case Report}

On July 27th 2017, dispatcher received phone call about traffic accident on regional road near the town. The detailed information was: two vehicles, three victims, one trapped in wreckage. Two teams were sent and the second team arrived first at the scene. Doctor examined the critical patient in wreckage first. EMT did several things; firstly: identified other patients, secondly: triaged them and both were "yellow", thirdly -treated the injured. Technician did the first survey and identified injuries. Then he immobilized crashes and banded the wounds. After that he did second survey and waited for the first team. When the first team arrived on scene, EMT reported all information about patients to the doctor from the first team. With that he completed his first mission in saving victims [1].

Second mission is saving the patient from the wreckage with his main team. EMT went to the doctor from his team and received information about the patient who was "red" and still blocked in wreckage therefore had to be treated on the scene. EMT entered the car through the broken window and inserted IV cannula in patient's right arm. By the order of the doctor he connected IV infusion of saline solution and opened it in the jet. Then he was set noninvasive cardiac and SpO2 monitor. At the same time the doctor kept opened airway, gave support to the patient and coordinated between medical and firefighters team. Next assignment for EMT was cervical spine. Patient was in a specific position: laid on part of spinal board held by the driver. Right leg was stuck on gas pedal. The evacuation lasted around one hour. At the beginning, cervical spine stabilization was done by the firefighter. After IV administration of saline solution EMT took over while firefighter went to second position near the head of the patient and helped in stabilization of head and cervical spine with cervical collar. The next stage was extraction. Firefighters freed the patient while the doctor was in the vehicle but all the other people were out of it. EMT coordinated between the doctor and firefighters. Extraction was completed in four steps: 1 . the doctor held the broken leg, 2. EMT held head and neck, 3. the driver held spinal board and 4. Three firefighters pulled the patient out from the crashed vehicle. When patient was completely on the board the members of the both teams took hold of the board and put it on a stretcher. Doctor mounted head blocks while the technician and the driver mounted spider belts. When EMT checked the monitor, electrodes, IV route and the belts it could be preceded with the transport.'

\section{Discussion}

Emergency medical technician plays important role in saving traffic accidents victims. Though all emergency medical teams have three members, sometimes technician has to take full responsibility for patient treatment. In mass casualties EMT has very important role: triage of all the injured and categorizing them in red, yellow, green or black groups with cards and START triage system. If the number of casualties is from three to five the 
"complex" triage system is used for all emergency teams: medical, firefighters and police (Figure 1). First member from each team uses this system for triage and categorizing victims. Medical team, if arrived second, divides: doctor treats the most serious patient while EMT triages, does first then second survey and treatment for all other victims. After arrival of other medical teams, EMT and the doctor treat one patient [2].
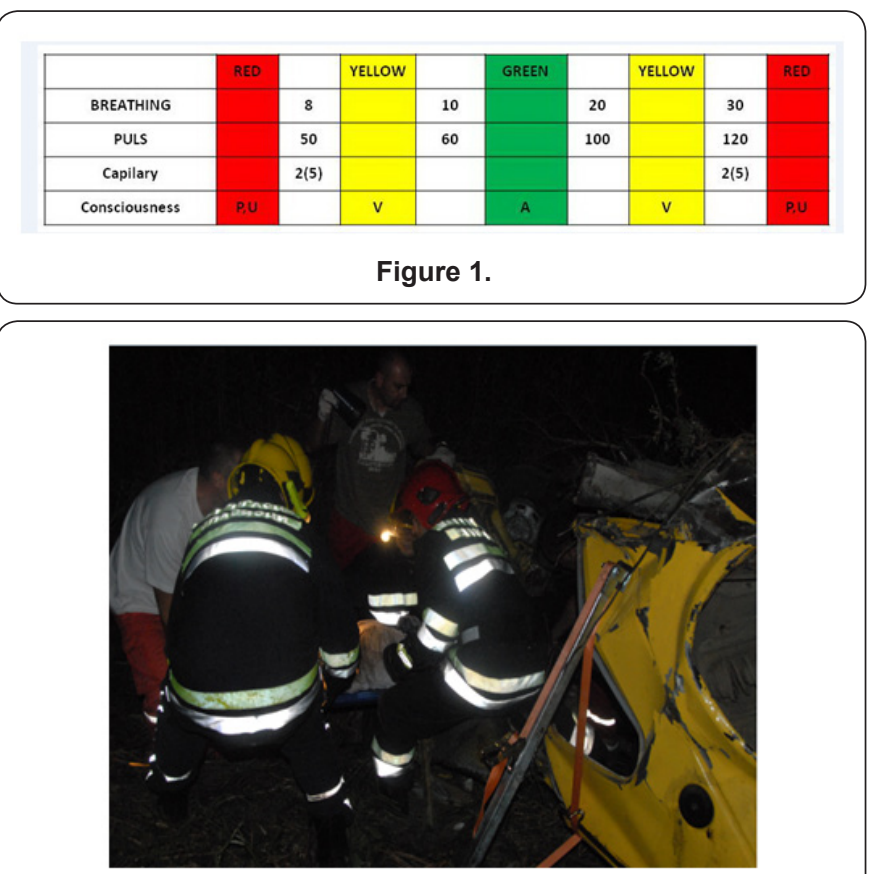

Figure 2.
For treating patients system "Stay and Play" is used in Serbia. It means that all procedures are done on the scene. EMT is doctor's assistant in some procedures such as endotracheal intubation, aspiration, monitoring, immobilizing etc. Some procedures have to be done by EMT alone or with firefighter or policeman as chief of the team. For instance: cervical spine stabilization with collar, extremity immobilization, IV cannulation, fixation of the patient on board etc. Extraction from the wreckage is specific. EMT has to stabilize head and cervical spine and coordinate between doctor and firefighters at the same time (Figure 2).

\section{Conclusion}

After traffic accident in Serbia medical team has to complete many procedures at the scene and then start the transport to the hospital. During these procedures, EMT has great responsibility and patient treatment quality depends on his work.

\section{References}

1. Salomone J, Pons P, Giebner S, Guj J (2011) Prehospital Trauma Life Support. Prehospital Trauma Life Support Committee of the National Association of Emergency Medical Technicians in Cooperation with The Committee on Trauma of The American College of Surgeons, St Louis, USA.

2. Perge G, Milic S, Malesic S (2017) Saving Victims in Mass Casualty Incidents, Traffic Accidents and Catastrophes. Traffic Safety Committee, Belgrade, Serbia.

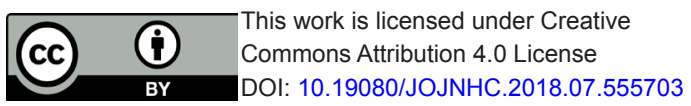

\section{Your next submission with Juniper Publishers will reach you the below assets}

- Quality Editorial service

- Swift Peer Review

- Reprints availability

- E-prints Service

- Manuscript Podcast for convenient understanding

- Global attainment for your research

- Manuscript accessibility in different formats

( Pdf, E-pub, Full Text, Audio)

- Unceasing customer service

Track the below URL for one-step submission https://juniperpublishers.com/online-submission.php 